\title{
Hubungan Pengetahuan Remaja Tentang HIV/AIDS Dengan Sikap Pencegahan HIV/AIDS Di SMA Negeri 1 Gurah Kabupaten Kediri
}

\author{
Arika Indah Setyarini, Ira Titisari, Putri Adi Ramadhania \\ Prodi Kebidanan Kediri Jl.KH.Wakhid Hasyim 64 B Kediri \\ Email : arika1mkeb@gmail.com
}

\begin{abstract}
Almost every week the prostitution in Gurah are visited by teenager from junior, senior high school and college student. This things caused the knowledge about HIV/AIDS is still less so made the attitude is worst too. The purpose of this study was to analyze the correlation between knowledge of teenager about HIV / AIDS with HIV/AIDS prevention attitude of HIV / AIDS in State 1 Senior High School Gurah, District Kediri. This study used cross sectional method. The number of population is 198 and samples was 67 according to the inclusion and exclusion criteria used stratified proportional random sampling and simple random sampling technique. Data was collected using a questionnaire and analyzed using Spearman rank correlation test. The analyzed result used Spearman test with an error level of 5\% $(0,05)$ used the formula $\rho, \rho=0,62$, because sample are 67 so it's calculated used t formula with result $t=6,36$. Then the $t$ compared to the $t$ table and got the result $t$ value $(6,36)>t$ table $(1,996)$, which means Ho is rejected and it means there is a correlation between knowledge of teenager about HIV / AIDS with HIV/AIDS prevention attitude of HIV / AIDS in State 1 Senior High School Gurah, District Kediri. The conclusion is good knowledge will influence the good attitude too. So that, suggested that teenagers should more added knowledge about HIV/AIDS so the knowledge will be better.
\end{abstract}

\section{Keywords : HIV/AIDS, Knowledge, Teenager, Attitude}

\section{Pendahuluan}

Pengetahuan adalah segala sesuatu yang diperoleh manusia melalui kegiatan akal pikiran atau akal budi manusia. Salah satunya adalah permasalahan yang dihadapi remaja. (Apriyani. 2012). Mereka umumnya memiliki dorongan seksual yang sangat kuat, sedangkan risiko akibat kegiatan seksual yang menjurus pada hubungan seks belum sepenuhnya mereka ketahui. (Surbakti.2009:107).

Perkembangan jaman saat ini, ikut mempengaruhi sikap seksual dalam berpacaran remaja. Hal ini misalnya dapat dilihat bahwa hal-hal yang ditabukan oleh remaja pada beberapa tahun yang lalu, seperti berciuman dan bercumbu kini telah dibenarkan oleh remaja sekarang. Bahkan ada sebagian kecil dari mereka setuju dengan free sex. Kondisi tersebut dapat menyebabkan Kasus Kehamilan Tidak Diinginkan (KTD) yang selanjutnya memicu praktik aborsi yang tidak aman, penularan Penyakit menular Seksual (PMS) dan Human Immunodeficiency Virus atau HIV dan Acquired Immuno Deficiency Syndrome atau biasa disebut AIDS, bahkan kematian. (Azinar.2013 : 138).

Data laporan kasus HIV/AIDS menurut Kementrian Kesehatan Indonesia selama 5 tahun terakhir.

Tabel 1 Data Laporan Kasus HIV/AIDS di Indonesia

\begin{tabular}{ccc}
\hline TAHUN & HIV & AIDS \\
\hline 2008 & 10.362 & 5.134 \\
2009 & 9.793 & 5.458 \\
2010 & 21.591 & 6.476 \\
2011 & 21.031 & 6.178 \\
2012 & 9.883 & 3.541 \\
\hline
\end{tabular}

(Dirjen PP \& PL Kemenkes RI.2013.2) 
Sebanyak 15.273 kasus HIV dan 7.714 kasus AIDS terjadi di Jawa Timur dan diantaranya sebanyak 872 kasus ditemukan pada usia 15-24 tahun. (Aditama.2013:2). Kabupaten Kediri termasuk dalam 10 besar tertinggi penemuan kasus HIV/AIDS di Jawa Timur, dengan jumlah kasus pada tahun 2013, HIV sebanyak 518 dan kasus AIDS sebanyak 249. Berdasarkan golongan umur, besar kasus HIV/AIDS tertinggi terjadi pada usia 15-24 sebanyak 78 kasus dan umur 25-39 sebanyak 205 kasus. (Munawaroh.2014).

Cara penularan kasus AIDS kumulatif dilaporkan melalui hubungan seks heteroseksual (54,8\%), Injecting Drug User atau IDU (36,2\%), hubungan seks sesama lelaki (2,9\%), dan perinatal $(2,8 \%)$. Kelompok umur dengan kasus AIDS tertinggi adalah: kelompok umur 20-29 tahun, ini berarti jika sejak terinfeksi sampai masuk ke kondisi AIDS lamanya 5 tahun, maka usia terendah saat terinfeksi sekitar 15-24 tahun. (Subuh dan Sulistyowati.2012:6).

Faktor ketidaktahuan terkait penularan virus HIV masih menjadi masalah besar yang harus dibenahi karena masih banyak masyarakat yang belum tahu bagaimana penularan virus HIV. Pengetahuan itu tidak selalu identik dengan tingkat pendidikan. Misalnya, seseorang yang berpendidikan rendah tapi dia lebih rajin pergi ke posyandu, dia akan lebih tahu bagaimana proses penularan HIV ketimbang mereka yang punya pendidikan tinggi. (Kompas.com : Kasus AIDS Tertinggi di Jawa Timur).

Layanan kesehatan HIV/AIDS merupakan suatu wadah bukan hanya untuk mendapatkan servis pengobatan, akan tetapi juga sebagai upaya pencegahan untuk menekan jumlah penderita HIV/AIDS. Selain itu, layanan kesehatan ini juga memberikan wawasan dan ruang untuk konsultasi bagi masyarakat agar mengetahui lebih banyak informasi tentang HIV/AIDS sehingga dapat mengaplikasikan pengetahuannya dalam kehidupan sehari-hari. (Pratiwi.2011:5).

Dari hasil wawancara peneliti dengan kepala bagian Pencegahan dan Pengendalian Penyakit Menular Langsung (P2PL) Puskesmas Gurah, Umi Syayidah, S.Sos pada tanggal 25 Maret 2014, didapatkan data kasus HIV/AIDS yang terjadi oleh remaja di Desa Gurah sebanyak 3 kasus pada tahun 2013, yaitu pada kelompok usia 20 tahun, 22 tahun dan 24 tahun. Penyebab HIV/AIDS itu sendiri karena seks bebas dan Narkotika, Psikotropika dan Zat Adiktif (NAPZA).

Menurut Umi Syayidah, S.Sos, hampir setiap minggu tempat lokalisasi di Desa Gurah selalu didatangi oleh para remaja SMP hingga mahasiswa. Kurang lebih 10-25 mahasiswa setiap minggu mendatangi tempat lokalisasi yang ada di Gurah.

Riset Kesehatan Dasar tahun 2010 menyatakan, secara nasional baru $11,4 \%$ penduduk umur 15-24 tahun yang memiliki pengetahuan yang benar dan komprehensif tentang HIV dan AIDS. Tidak mungkin mengharapkan tidak terjadinya kasus baru infeksi HIV diantara kaum muda, jika mereka tidak tahu apa itu HIV dan AIDS, bagaimana cara menghindarkan dirinya dari terinfeksi HIV, tidak tahu bagaimana HIV dapat menular dan jika mereka bahkan tidak tahu bahwa mereka mengidap HIV atau tidak. (Subuh dan Sulistyowati.2012:7-8).

Berdasarkan data di atas, maka peneliti tertarik melakukan penelitian dengan judul "Hubungan Pengetahuan Remaja tentang HIV/AIDS dengan Sikap Pencegahan HIV/AIDS di SMA Negeri 1 Gurah, Kabupaten Kediri”.

\section{Metode Penelitian}

Populasi dalam penelitian ini adalah siswa dan siswi kelas X SMA Negeri 1 Gurah yang berjumlah 198 orang. Teknik ini dinamakan stratified proportional random sampling. Sehingga sampel yang diperoleh:

Kelas XA : (34/198) x $67=11$ orang 
Kelas XB : $(32 / 198) \times 67=11$ orang Kelas XC : $(33 / 198)$ x $67=11$ orang Kelas XD : $(35 / 198)$ x $67=12$ orang Kelas XE : $(33 / 198) \times 67=11$ orang Kelas XF : $(32 / 198) \times 67=11$ orang Total : 67 orang

Melakukan analisa data untuk mengetahui hubungan pengetahuan remaja tentang HIV/AIDS dengan sikap pencegahan HIV/AIDS adalah dengan menggunakan uji statistic non parametis Spearman Rank.

\section{Hasil Penelitian}

1. Pengetahuan Remaja Tentang HIV/AIDS

Berdasarkan tabel 1 dapat dijelaskan bahwa lebih dari 50\% responden memiliki

\begin{tabular}{llll}
\hline No & Kategori & Frekuensi & Persentase \\
\hline 1 & Baik & 59 & $88,06 \%$ \\
2 & Cukup & 7 & $10,45 \%$ \\
3 & Kurang & 1 & $1,49 \%$ \\
\hline \multicolumn{2}{l}{ Total } & 67 & $100 \%$ \\
\hline
\end{tabular}

pengetahuan yang baik tentang HIV/AIDS yaitu sebesar $88,06 \%$.

2. Sikap Pencegahan HIV/AIDS

\begin{tabular}{llll}
\hline No & Kategori & Frekuensi & Persentase \\
\hline 1 & Sangat Baik & 54 & $80,60 \%$ \\
2 & Baik & 13 & $19,40 \%$ \\
3 & Tidak Baik & 0 & 0 \\
4 & Sangat Tidak & 0 & 0 \\
& Baik & & \\
\hline Total & 67 & $100 \%$ \\
\hline
\end{tabular}

Berdasarkan tabel 2 tersebut dapat dijelaskan bahwa sebagian besar responden memiliki sikap yang sangat baik terhadap pencegahan HIV/AIDS, yaitu sebesar $(80,60 \%)$.
3. Hubungan Pengetahuan Remaja tentang HIV/AIDS dengan Sikap Pencegahan HIV/AIDS

\begin{tabular}{|c|c|c|c|c|c|}
\hline \multicolumn{6}{|c|}{ Sikap Pencegahan } \\
\hline $\begin{array}{l}\text { Pengeta } \\
\text { huan }\end{array}$ & $\begin{array}{l}\text { Sangat } \\
\text { Baik }\end{array}$ & Baik & $\begin{array}{l}\text { Tidak } \\
\text { Baik }\end{array}$ & $\begin{array}{l}\text { Sangat } \\
\text { Tidak } \\
\text { Baik }\end{array}$ & Jumlah \\
\hline Baik & $\begin{array}{l}54 \\
(80,60 \\
\%)\end{array}$ & $\begin{array}{l}5 \\
(7,5 \%)\end{array}$ & & & $88,1 \%$ \\
\hline Cukup & & $\begin{array}{l}7 \\
(10,5 \%)\end{array}$ & $\begin{array}{l}7 \\
(9,5 \%)\end{array}$ & & $10,5 \%$ \\
\hline Kurang & & $\begin{array}{l}1 \\
(1,5 \%)\end{array}$ & & & $1,5 \%$ \\
\hline Jumlah & $80,60 \%$ & $19,4 \%$ & $9,46 \%$ & & $100 \%$ \\
\hline
\end{tabular}

Berdasarkan tabel silang antara pengetahuan remaja tentang HIV/AIDS dengan sikap pencegahan HIV/AIDS sebagian besar responden mempunyai pengetahuan yang baik dan memiliki sikap pecegahan yang sangat baik, yaitu sebesar (80,60\%). Kemudian untuk mengetahui hubungan antara pengetahuan remaja tentang HIV/AIDS dengan sika pencegahan HIV/AIDS digunakan rumus:

$$
\rho=1-\frac{6 \sum b_{i}^{2}}{n\left(n^{2}-1\right)}
$$

Berdasarkan perhitungan tersebut didapatkan hasil, $\rho=0,62$. Karena jumlah sampel lebih dari 30, dimana tidak ada dalam tabel rho, maka pengujian signifikansinya menggunakan rumus:

$$
t=r \sqrt{\frac{n-2}{1-r^{2}}}
$$

Berdasarkan hasil perhitungan menggunakan uji korelasi spearman dengan taraf kesalahan sebesar 5\% $(0,05)$ maka diperoleh hasil perhitungan $\mathrm{t}=$ (6,36). Kemudian $\mathrm{t}$ hitung tersebut dibandingkan dengan $\mathrm{t}$ tabel, dan didapatkan $\mathrm{t}$ hitung 6,27 > t tabel 1,996 maka Ho ditolak dan H1 diterima, artinya ada hubungan antara pengetahuan remaja tentang HIV/AIDS dengan sikap pencegahan HIV/AIDS di SMA Negeri 1 Gurah Kabupaten Kediri. 


\section{Pembahasan}

\section{Pengetahuan Remaja tentang HIV/AIDS di SMA Negeri 1 Gurah, Kabupaten Kediri}

Berdasarkan hasil penelitian yang telah dilakukan pada tanggal 17 Juni 2014 didapatkan data bahwa lebih dari 50\% responden memiliki pengetahuan yang baik tentang HIV/AIDS yaitu sebesar $88,06 \%$, sedangkan sisanya memiliki pengetahuan yang cukup sebesar 10,45\% dan pengetahuan yang kurang hanya $1,49 \%$.

Pengetahuan remaja di SMA Negeri 1 Gurah Kabupaten Kediri yang sebagian besar adalah baik disebabkan karena mereka pernah mendapat informasi tentang HIV/AIDS dari Komisi Penanggulangan HIV/AIDS (KPA) pada tanggal 13 Juni 2014. Kondisi tersebut juga disebabkan karena pendidikan kesehatan reproduksi telah dilaksanakan di sekolah mereka mulai dari kelas X, XI IPA dan XII IPA. Materi yang disampaikan pada kelas $\mathrm{X}$ menyangkut tentang alat-alat genetalia laki-laki dan perempuan beserta fungsinya. Materi tentang HIV/AIDS juga pernah disampaikan sekilas beberapa kali terkait dengan materi mengenai organ genetalia laki-laki dan perempuan.

Berbagai bentuk media juga telah digunakan oleh pihak guru untuk menyebarluaskan informasi tentang HIV/AIDS, seperti poster dan pamflet tentang HIV/AIDS yang terpasang di majalah dinding siswa. Hasil penelitian tersebut dapat juga dikatakan bahwa SMA Negeri 1 Gurah menyediakan fasilitas yang dapat mendukung atau mempermudah responden dalam mengakses segala informasi mengenai HIV/AIDS. Contohnya, tersedianya perpustakaan sekolah yang mempunyai beberapa buku tentang HIV/AIDS, laboratorium komputer atau internet sehingga memungkinkan para siswa untuk memperoleh informasi mengenai HIV/AIDS.
Sesuai hasil penelitian, menunjukkan bahwa sebagian besar responden menjawab benar pada pertanyaan pengertian tentang HIV. Ini berarti pengetahuan remaja tentang pengertian HIV sudah baik. Tetapi sebagian besar responden menjawab salah pada soal tentang tanda gejala penyait HIV/AIDS, ini berarti pengetahuan remaja tentang tanda dan gejala HIV/AIDS masih kurang. Hasil penelitian juga menunjukkan bahwa sebagia besar responden yang memiliki sumber informasi lebih dari empat, mempunyai pengetahuan yang lebih baik dibandingkan responden yang memiliki sumber informasi satu sampai empat.

Hal tersebut sejalan dengan penelitian Hardiningsih (2011) yang menyimpulkan adanya pengaruh positif pendidikan kesehatan reproduksi terhadap meningkatnya pengetahuan tentang HIV/AIDS. Faktor lainnya terkait pengetahuan HIV dan AIDS didapatkan remaja sebagian besar melalui media yang ada di sekolah, seperti poster dan pamflet tentang HIV/AIDS yang terpasang di majalah dinding siswa dan laboratorium komputer atau internet sehingga siswa dapat mengakses informasi yang terkait dengan HIV/AIDS.

Menurut teori yang dikemukakan Notoatmodjo (2003) bahwa melalui berbagai media baik cetak maupun elektronika, berbagai informasi dapat diterima oleh masyarakat, sehingga seseorang yang lebih sering terpapar media masa (TV, radio, majalah, pamflet) akan memperoleh informasi yang lebih dibandingkan dengan orang yang tidak pernah terpapar informasi media masa. Hal tersebut sejalan dengan teori Widyatun (2004) bahwa semakin banyak informasi yang masuk maka semakin banyak pengetahuan yang didapat termasuk informasi mengenai kesehatan.

Menurut peneliti, terdapatnya siswa yang memiliki pengetahuan cukup $(10,45 \%)$ dan kurang $(1,49 \%)$ dapat disebabkan karena situasi dan kondisi pada saat pemberian pendidikan kesehatan 
reproduksi yang menyangkut materi tentang HIV/AIDS hanya dijelaskan sekilas saja dan tidak sampai tuntas. Materi tentang HIV/AIDS hanya pernah disampaikan oleh guru siswa sebatas cara penularan HIV/AIDS salah satunya melalui berhubungan seks secara bebas, sedangkan hal-hal lain terkait tanda gejala, pengertian HIV/AIDS dan cara penularan HIV/AIDS yang lain belum pernah dibahas. Faktor lain yang menyebabkan siswa mempunyai pengetahuan kurang yaitu metode yang digunakan pada saat pemberian pendidikan tersebut adalah metode ceramah.

Menurut Tarigan (2010), metode diskusi kelompok lebih efektif dalam meningkatkan pengetahuan tentang kesehatan reproduksi, salah satunya tentang HIV/AIDS pada remaja dibandingkan dengan metode ceramah. Menurut Porter dan Kemacki dalam Suryani (2006) juga menyatakan bahwa kemampuan individu untuk menyerap informasi melalui indera pendengaran sangat terbatas. Dari hal ini dapat diperkirakan kemampuan individu untuk mengingat informasi yang diterima kurang, sehingga akan memberikan tingkat pengetahuan yang berbeda-beda pula.

\section{Sikap Pencegahan HIV/AIDS di SMA Negeri 1 Gurah, Kabupaten Kediri}

Berdasarkan hasil penelitian yang didapatkan dari 67 remaja yang menjadi responden sebagian besar remaja memiliki sikap pencegahan HIV/AIDS yang sangat baik yaitu sebesar $80,60 \%$ dan sisanya memiliki sikap baik sebesar 19,40\%. Sedangkan tidak ada satu pun responden yang memiliki sikap pecegahan HIV/AIDS yang tidak baik ataupun sangat tidak baik.

Menurut hasil penelitian, didapatkan sebagian besar responden menjawab setuju pada pernyataan yang bersifat positif dan sebagian besar menjawab tidak setuju pada pernyataan yang bersifat negatif. Hal ini yang membuat sikap remaja terhadap pencegahan HIV/AIDS baik.

Perbedaan sikap pada remaja ini dapat dipengaruhi oleh kondisi masingmasing individu, cara pandang dan latar belakang. Jika dipahami penyebab perbedaan ini sifatnya sangat subyektif. Oleh karena itu, perbedaan sikap merupakan hal biasa dan harus dipahami sebagai bentuk keunikan tiap individu. Semakin berkembangnya pola pikir serta bertambahnya pengalaman bersama teman, keluarga dan masyarakat menjadikan remaja tersebut memilah mana yang baik dan mana yang buruk untuk dirinya sehingga terbentuk suatu sikap dalam diri remaja tersebut. Menurut Azwar (2005) bahwa faktor pengalaman pribadi juga dapat mempengaruhi pembentukan sikap seseorang.

Sikap merupakan perasaan mendukung dan perasaan tidak mendukung (Azwar, 2005). Pembentukan sikap juga memerlukan dukungan dari orang lain. Pada penelitian ini teman sebaya dan guru merupakan orang lain terdekat dengan remaja yang selalu memberi dukungan bagi setiap sikap yang akan dilakukan oleh remaja terkait pencegahan HIV/AIDS. Hal ini didukung teori Azwar (2005) yang mengatakan bahwa orang lain di sekitar kita merupakan salah satu diantara komponen sosial yang ikut mempengaruhi pembentukan sikap terhadap sesuatu.

Kepercayaan dan keyakinan yang terbentuk dalam suatu keluarga atau lingkungan masyarakat sekitar juga ikut mempengaruhi sikap remaja. Pada penelitian ini menunjukkan bahwa mayoritas responden mempunyai sikap tidak setuju apabila berjabat tangan atau makan bersama penderita HIV/AIDS dapat membuat kita tertular. Keyakinan atau kepercayaan tersebut dapat dikarenakan pengaruh dari lingkungan sekitar, seperti keluarga dan teman sebaya yang akhirnya akan menentukan pembentukan sikap seseorang. Pada tahap 
perkembangan remaja, pengaruh teman sebaya sangat tinggi. Siswa banyak membentuk kelompok-kelompok untuk memperoleh informasi-informasi sehingga mempengaruhi sikap remaja.

Menurut Lawrence Green (1980) dalam Notoatmojo (2003) sikap ditentukan atau terbentuk dari 3 faktor. Faktor predisposisi (Predisposing Factor) meliputi pengetahuan sikap, kepercayaan, keyakinan, nilai-nilai dan sebagainya yang terdapat dalam diri individu maupun masyarakat. Faktor pendukung (Enabling Factors) meliputi lingkungan fisik seperti umur, status sosial ekonomi, pendidikan, sumber daya atau potensi masyarakat. Faktor pendorong (Renforcing factor) meliputi sikap dan sikap orang lain. Misalnya : sikap orang tua, suami, tokoh masyarakat atau petugas kesehatan.

Adanya pendidikan keagamaan yang telah diajarkan kepada remaja baik di lingkungan pendidikan maupun di lingkungan keluarga juga dapat mempengaruhi sikap remaja tersebut. Hal ini sesuai dengan teori Wawan (2011) yang mengatakan bahwa konsep moral dan ajaran dari lembaga pendidikan dan lembaga agama sangat menentukan sistem kepercayaan sehingga konsep tersebut akan mempengaruhi sikap. Gambaran sikap seseorang terhadap suatu obyek responden mengenai HIV/AIDS dapat dipengaruhi oleh beberapa hal yaitu diantaranya pengalaman pribadi, media massa, pengaruh orang lain yang dianggap penting, pengaruh kebudayaan, lembaga pendidikan dan lembaga agama dan faktor emosional (Wawan.2011).

\section{Hubungan Pengetahuan Remaja Tentang HIV/AIDS dengan Sikap Pencegahan HIV/AIDS di SMA Negeri 1 Gurah Kabupaten Kediri}

Berdasarkan hasil perhitungan menggunakan uji korelasi spearman dengan taraf kesalahan sebesar 5\% $(0,05)$ maka diperoleh hasil perhitungan $\mathrm{t}=$ $(15,73)$. Kemudian $\mathrm{t}$ hitung tersebut dibandingkan dengan $\mathrm{t}$ tabel, dan didapatkan t hitung 15,73>t tabel 1,996 maka Ho ditolak dan $\mathrm{H} 1$ diterima, artinya ada hubungan antara pengetahuan remaja tentang HIV/AIDS dengan sikap pencegahan HIV/AIDS di SMA Negeri 1 Gurah, Kabupaten Kediri.

Berdasarkan hasil penelitian yang didapatkan dari 67 remaja yang menjadi responden didapatkan hasil tabulasi antara pengetahuan remaja tentang HIV/AIDS baik dengan sikap pencegahan sangat baik HIV/AIDS berjumlah 54 responden $(80,60 \%)$.

Sikap yang dimiliki oleh remaja di SMA Negeri 1 Gurah Kabupaten Kediri yang sebagian besar sangat baik ini disebabkan karena remaja sudah cukup mendapat pengetahuan tentang HIV/AIDS baik dari lingkungan maupun sekolah. Pengetahuan akan menumbuhkan sikap dalam diri seseorang. Menurut Horton dalam Suryani (2006), pemilahan dari pengetahuan dan pengamatan inilah yang menghasilkan sikap individu.

Siswa telah mendapatkan pendidikan yang cukup dari sekolah maupun lingkungan. Misalnya pendidikan reproduksi yang menyangkut tentang materi HIV/AIDS yang telah diajarkan di sekolah merupakan salah satu faktor yang mempengaruhi pengetahuan siswa. Hal tersebut memberikan informasi kepada siswa yang akhirnya membuat siswa dapat berfikir dan menentukan sikap. Hal ini sesuai dengan Baron (2006) bahwa pengetahuan merupakan suatu faktor kekuatan terbentuknya sikap seseorang. Penelitian ini menunjukkan bahwa pengetahuan yang baik akan mendukung sikap yang baik pula. Adanya suatu pengetahuan tentang HIV/AIDS dapat mempengaruhi siswa untuk bersikap sesuai pengetahuan yang di dapat.

Penelitian ini sesuai dengan hasil penelitian yang dilakukan oleh Fatusi (2004) bahwa responden yang memiliki pengetahuan baik aka memiliki sikap yang baik pula. Wigati (2007) dalam penelitiannya menyimpulkan bahwa pengetahuan yang baik akan mendukung 
sikap remaja yang baik tentang HIV/AIDS. Hal ini sejalan dengan penelitian Sri Handayani (2003) bahwa terdapat hubungan yang bermakna antara pengetahuan tentang HIV/AIDS dengan sikap pencegahan HIV/AIDS. Hasil penelitian Kunhastuti (2003), bahwa ada hubungan antara pengetahuan dan sikap remaja tentang pencegahan HIV/AIDS. Hasil penelitian ini juga sejalan dengan Susilawati (2003) dan Prawita (2006), bahwa ada hubungan antara pengetahuan dan sikap pencegahan HIV/AIDS.

Sesuai yang dikemukakan oleh Notoatmodjo bahwa pengetahuan yang baik akan menimbulkan sikap positif pada seseorang. Namun, penelitian ini menunjukkan masih ada responden dengan nilai pengetahuan yang cukup dan sikap baik $(10,45 \%)$ dan pengetahuan kurang tetapi sikap baik $(1,49 \%)$.

Siswa yang mempunyai pengetahuan kurang tetapi sikap pencegahannya baik dapat juga dikarenakan siswa tersebut terpengaruh sikap orang lain yang sering dilihatnya, seperti orang tua dan teman. Padahal mereka belum mengetahui pengetahuan yang benar tentang apa yang dilakukannya tersebut. Contohnya, seorang responden yang mempunyai pengetahuan bahwa HIV/AIDS adalah penyakit kutukan Tuhan, tetapi ternyata sikap siswa tersebut baik. Hal ini sangat mungkin terjadi karena sikap seseorang tidak selalu ditentukan dari tingkat pengetahuan saja, artinya jika pengetahuannya baik belum tentu mencerminkan sikap yang baik atau positif, begitu pula sebaliknya.

Menurut Azwar (2011) untuk memperoleh sikap yang mendukung tidak hanya diperlukan pengetahuan saja, tetapi dipengaruhi juga oleh faktor emosional, pengalaman pribadi, media massa, lembaga pendidikan, pengaruh orang lain yang dianggap penting, dan kebudayaan.

\section{Kesimpulan}

1. Sebagian besar pengetahuan remaja tentang HIV/AIDS di SMA Negeri 1 Gurah Kabupaten Kediri adalah baik.

2. Sebagian besar sikap pencegahan HIV/AIDS remaja di SMA Negeri 1 Gurah Kabupaten Kediri adalah sangat baik.

3. Ada hubungan pengetahuan remaja tentang HIV/AIDS dengan sikap pencegahan HIV/AIDS di SMA Negeri 1 Gurah Kabupaten Kediri.

\section{Saran}

1. Bagi Peneliti Selanjutnya

Hasil penelitian ini diharapkan bisa dijadikan bahan untuk peneliti selanjutnya dengan memperluas variabel-variabel lainnya, misalnya perilaku.

2. Bagi Institusi Pendidikan

Hasil penelitian ini diharapkan dapat dijadikan sebagai sumber informasi sekaligus dasar untuk pengembangan penelitian selanjutnya yang berhubungan tentang pengetahuan, sikap dan HIV/AIDS.

3. Bagi Tempat Penelitian

Diharapkan siswa dapat mempertahankan hasil pengetahuannya yang sudah baik dengan tetap memperbarui informasi-informasi terkait HIV/AIDS dan bagi pihak sekolah agar lebih meningkatkan lagi cara penyampaian materi tentang HIV/AIDS kepada para siswa, misalnya dengan memperlihatkan video tentang kasus HIV/AIDS yang terjadi pada remaja dan akibat yang ditimbulkan.

\section{Daftar Pustaka}

Aditama, T.Y., Prof., Dr. 2010. Statistik Kasus HIV/AIDS di Indonesia Dilapor. Diunduh dari www.aidsdatahub.org tanggal 3 Februari 2014 jam10:07 WIB.

Apriyani, S. 2012. Hubungan Antara Pengetahuan Dengan Sikap Seksual Pranikah Remaja. 
Anonim. 2012. Info HIV dan AIDS. Diakses dari aidsindonesia.or.id tanggal 5 Maret 2014 jam 8:27 WIB.

. 2012. Program Pengendalian Penyakit Menular di Jawa Timur. Diunduh dari dinkes.jatimprov.go.id pada tanggal 3 Februari 2014 jam 11:12 WIB.

. 2007. Tahapan Perkembangan Remaja. Diakses dari www.fighislam.com pada tanggal 4 maret 2014 jam 10:49 WIB.

2010. Uji Validitas. Diakses dari statmisker.wordpress.com tanggal 1 Maret 2014 jam 11:26 WIB.

Azinar, M. 2013. Perilaku Seksual Pranikah Berisiko Terhadap Kehamilan Tidak Diinginkan. Jurnal Kesehatan Masyarakat. 1-9.

Azwar, S. 2005. Sikap Manusia : Teori dan Pengukurannya. Yogyakarta : Pustaka Pelajar.

Budiamin, A. Penilaian Sikap. Diunduh dari file.upi.edu tanggal 12 Maret 2014 jam 21:27 WIB.

Efendi, F. dan Makhfudli. 2009. Keperawatan Kesehatan Komunitas. Jakarta : Salemba Medika.

Eriyanto. 2007. Teknik Sampling Analisis Opini Publik. Yogyakarta : LkiS.

Handayani, S. 2007. Pengetahuan dan Sikap Siswa SMA Tentang HIV/AIDS di SMU Negeri 1 Wedi Klaten. Diunduh dari portalgaruda.org tanggal 13 Maret 2014 jam 7:15 WIB.

Hidayat. A.A.A. 2010. Metode Penelitian Kebidanan Teknik
Analisis Data. Jakarta : Salemba Medika.

Kusmiran, E. 2011. Kesehatan Reproduksi Remaja dan Wanita. Jakarta : Salemba Medika.

Mertamupu, I.K. 2012. Seks Bebas dan Penanggulangannya perspektif Hiindu. Diakses dari edukasi.kompasiana.com pada tanggal 12 Maret 2014 jam 21:15 WIB.

Mikrajuddin, A., dkk. 2007. Ipa Terpadu SMP dan MTs Jilid 3A. Jakarta : Esis.

Munawaroh, N. 2014. Situasi HIV-AIDS Kab. Kediri. Didapatkan tanggal 28 Februari jam 20:08 WIB

Nenggala, A.K. 2006. Pendidikan Jasmani, Olahraga, dan Kesehatan. Jakarta : Grafindo Media Pratama.

Nisathahrinnisa. 2013. Cara Mengukur Sikap. Diakses dari nisathahrinnisa.wordress.com tanggal 12 Maret 2014 jam 21:26 WIB.

Notoatmodjo, S. 2005. Metodologi Penelitian Kesehatan. Jakarta : Rineka Cipta.

2012. Metodologi Penelitian Kesehatan. Jakarta : Rineka Cipta.

Noviana, N, SST, M.Kes. 2013. Catatan Kuliah Kesehatan Reproduksi \& HIV-AIDS. Jakarta : Info Media.

Nursalam, Dr., M.Nurs. dan Kurniawati, N.D., S.Kep.Ns. 2007. Asuhan Keperawatan pada Pasien Terinfeksi HIV/AIDS. Jakarta : Salemba Medika. 
Nursalam. 2008. Konsep dan Penerapan Metodologi Penelitian Ilmu Keperawatan. Jakarta: Salemba Medika.

Sarwono, S.W. 2013. Psikologi Remaja. Jakarta : RajaGrafindo Persada.

Soetjiningsih, Prof., dr., SpA(K), IBCLC. 2004. Tumbuh Kembang Remaja dan Permasalahannya. Jakarta : Sagung Seto.

Subuh, M.,Dr., H., MPPM dan Sulistyowati, L.S. dr. MM. 2012. Buku Petunjuk Penggunaan KIE versi pelajar. Jakarta.

Sugiyono. 2011. Metode Penelitian Kualitati, Kuantitaif dan $R \& D$. Bandung : Alfabeta.
Sunaryo. 2004. Psikologi Untuk Keperawatan. Jakarta : EGC.

Surbakti, E.B., Drs., M.A. Kenalilah Anak Remaja Anda. 2009 . Jakarta : Gramedia.

Wahareni, P.A. 2006. Sikap Remaja Terhadap Perilaku Seks Bebas Ditinjau dari Tingkat Penalaran Moral Pada Siswa Kelas Dua SMA Kesatrian 1 Semarang. Diunduh dari twitdoc.com tanggal 12 Maret 2014 jam 21.25 WIB.

Wijaya, C. 2009. Tingkat Pengetahuan dan Sikap Remaja dalam Mencegah HIV/AIDS di SMA Santo Thomas 1 Medan. Diunduh dari repository.usu.ac.id tanggal 12 Maret 2014 jam 23:00 WIB. 